\title{
Critics and Experts, Activists and Academics: Intellectuals in the Fight for Social and Ecological Justice in the Narmada Valley, India
}

\author{
PABLOS. B OSE
}

Summary: The following article examines the role of popular intellectuals in the rise of the Narmada Bachao Andolan, a mass-based movement opposed to the building of large dams in the Narmada Valley of central India. In particular, it focuses on two of this struggle's most prominent public figures and spokespersons, Medha Patkar and Arundhati Roy. The article examines the relationship between these individuals and the movement itself - how issues have been framed by Patkar and Roy for local, national, and international audiences, how support for the antidam struggle has been mobilized, and how each of these figures are themselves perceived and portrayed. The article will also examine some of the challenges faced by the movement and its leaders, not only from proponents of the dam projects, but also from other social activists and intellectuals. The latter have raised questions about representation, voice and strategy, as well as insider/outsider authenticity and legitimacy in the anti-dam movement, issues that this paper considers in some detail. Finally, the article draws on the Narmada case to ask some broader questions regarding popular intellectuals and social movement organizing and strategy.

\section{INTRODUCTION}

This paper examines the role of popular intellectuals in the rise of a massbased social and ecological justice movement mobilized against the building of large dams in the Narmada Valley of central India through the latter half of the twentieth century. This movement has enjoyed widespread support both nationally and internationally and has drawn upon a vibrant and longstanding local tradition of opposition to hydroelectric dam projects in order to raise questions about the nature and purpose of economic and social development in the region. In doing so, it has broadened its message, its appeal, and its constituency, fostering in the process regional, national, and even transnational networks of solidarity and support with regards to issues of sustainable development.

The story of Narmada is well known within the fields of development and social movement studies, a tale of diverse local communities and organizations coming together to challenge development authorities, state 


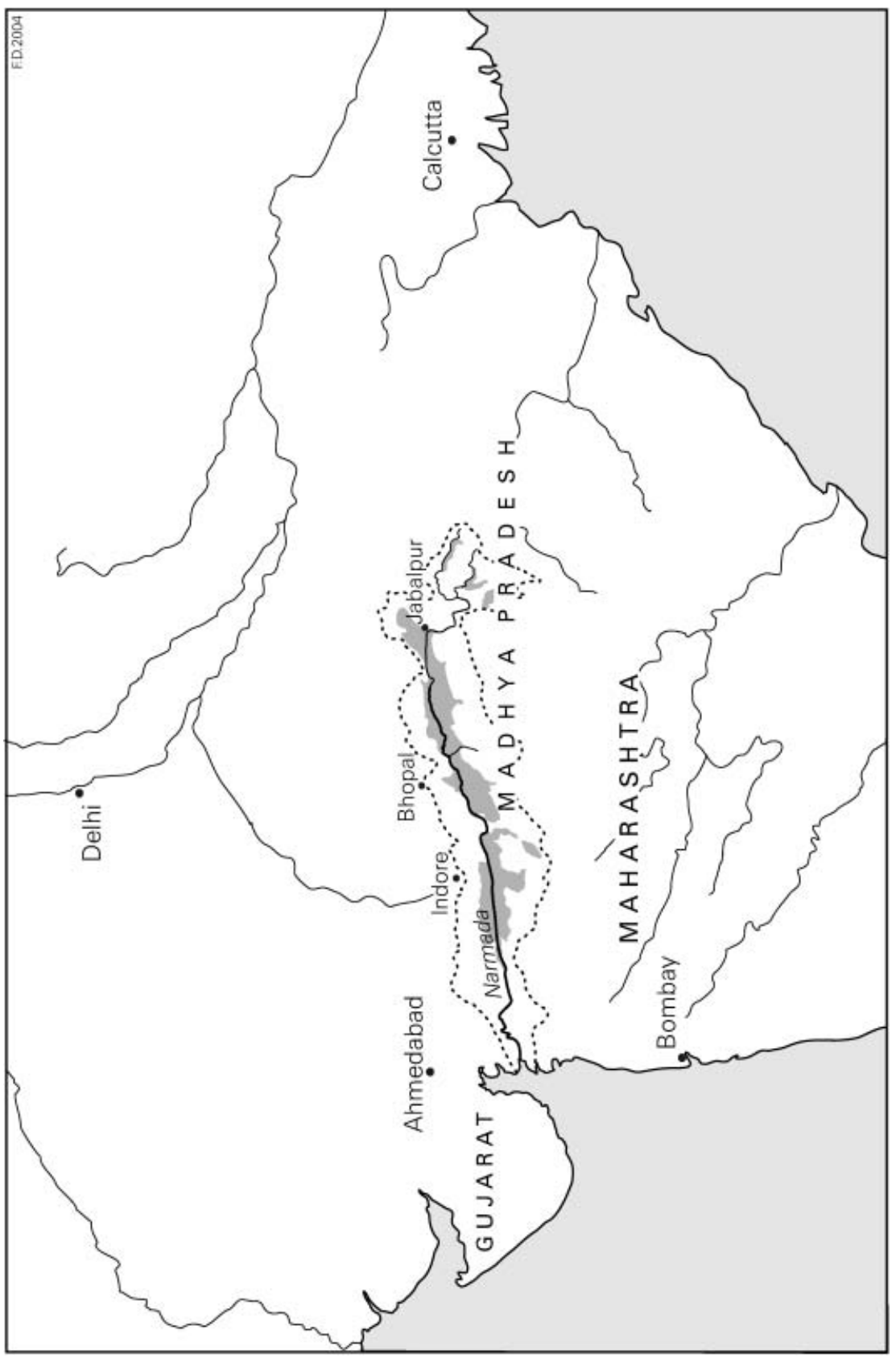

苞 
and national governments, and even the World Bank on their plans to redraw the social, physical, and economic landscapes of the region. What is less recognized is the complicated, confusing, and at the same time integral role played by popular intellectuals in this history.

There are two types of intellectuals particularly visible in the Narmada Valley - what Michel Foucault might distinguish as "critics" and "experts". ${ }^{I}$ The latter are a ubiquitous presence in the Narmada Valley, the legions of engineers, scientists, and administrators who have worked to plan, implement, and legitimize the Narmada Valley Development Project of an intricate series of interlinked dams. The "critics" are also numerous including environmental activists, social workers, university students, and labour organizers, as well as spokespeople and leaders from amongst the townsfolk, villagers, marginalized groups, and landless labourers who inhabit the proposed submergence zone.

It is many of these critics, with their multiple roles and diverse backgrounds, who I conceive of as the "popular intellectuals" of the Narmada conflict. They have helped to voice the concerns and opposition of local populations to the proposed project. They have also, through their empirical research, critical reflection, and careful analysis sought to understand the complex processes of nationalism, international development, and globalization that are intertwined and affect life in the Valley. Through organizing solidarity campaigns, broadening access to information, writing in scholarly journals and the popular press, making films and penning novels, they have intervened actively and directly in the political struggle gripping the Narmada region. They have challenged the state on its legitimizing claims of working "for the common good"; they have held private corporations and multilateral development agencies accountable for their actions. Indeed, as indicated earlier, their critique has extended beyond this set of projects to question the validity and efficacy of postcolonial development strategies within India itself. Popular intellectuals in the Narmada Valley have been instrumental in fostering links with other social justice struggles both within the subcontinent and internationally, helping to found the National Alliance of People's Movements in India, and forming strong solidarity ties with indigenous people's movements and social justice networks across the world.

The following paper focuses on one such set of "critics", gathered together under the umbrella of the social justice organization known as the Narmada Bachao Andolan (NBA), or the "Save Narmada Movement". This essay will examine the context and work of the NBA in four parts. In the first section, I provide a brief overview of the Narmada case and the rise of opposition to dams in the region in the form of the NBA. The next

I. Michel Foucault, "Truth and Power", in idem and Colin Gordon (ed.), Power/Knowledge: Selected Interviews and Other Writings 1972-1977 (New York, I980), pp. I 26-I 32. 
section focuses on two particular popular intellectuals - the NBA's leader, Medha Patkar, and one of its leading supporters, the novelist, Arundhati Roy. Both have become increasingly identified as the public faces of the Narmada struggle, much more so even than the many thousands of villagers scheduled to be displaced by the dams. I will look at how Patkar and Roy have attempted to frame the Narmada struggle, situating it within a broader political context, and linking it to other national and global issues. The third section will look at a series of public debates amongst Indian intellectuals and activists regarding the NBA and its leaders and supporters; in particular, at criticisms levied at Patkar and Roy, and the response that both they and others gave to such charges. In the final section, I will explore some of the broader questions that the Narmada case raises regarding the idea of "intellectuals" and their relation to progressive movements and social change. What role might "popular intellectuals" have to play in such struggles? What possibilities and problems might confront them and the movements on whose behalf they work?

\section{NARMADA VALLEY DEVELOPMENT PROJECTS AND THE "SAVE NARMADA MOVEMENT" (NBA)}

The Narmada is the fifth largest river in India, running for over $1300 \mathrm{~km}$ through the states of Madhya Pradesh, Maharashtra, and Gujarat, and spilling out into the Gulf of Cambay. Plans to build a series of dams in the Narmada Valley were first drawn up following India's independence in 1947. Construction began in the early I960s; however, disputes over project costs and benefits between various riparian states resulted in delays of over a decade as a federally appointed Water Disputes Tribunal sorted things out, announcing its award in 1978 after ro years of deliberation. The final outcome of the project envisions the construction of 30 major dams, I35 medium dams, 3,000 minor dams, and over 30,000 microharvesting (conservation) schemes throughout the Valley; 250,000 people will be directly displaced, while over a million will see their livelihoods disrupted or erased. This project is paralleled in size and scope by the Three Gorges Dam Projects in China. ${ }^{2}$

Proponents of the Narmada Valley Development Plan (NVDP) speak of the benefits it will bring, primarily in terms of drinking water, irrigation, and hydroelectric power. ${ }^{3}$ Gujarat, as the main beneficiary of the planned

2. For excellent overviews of the Narmada controversy see William F. Fisher (ed.), Toward Sustainable Development: Struggling Over India's Narmada River (London, 1995), and Sanjay Sangvai, The River and Life (Mumbai, 2000).

3. C.C. Patel, "Surging Ahead: The Sardar Sarovar Project, Hope of Millions", Harvard International Review, Is (1992), pp. 24-27; Mahesh Pathak (ed.), Sardar Sarovar Project: A Promise for Plenty (Gandhinagar, I99I); Sardar Sarovar Narmada Nigam Ltd website, available at http://www.sardarsarovardam.org. 
dams, will potentially see the irrigation of over $\mathrm{r} .8$ million hectares of land, the provision of drinking water to I 35 urban centres and 8,2 I 5 villages, the generation of over 200 megawatts (MW) of hydroelectric energy, and flood protection for 210 villages as well as the major city of Bharuch. The remaining energy production from the project will be divided between the states of Madhya Pradesh (800 MW) and Maharashtra (400 MW). Additionally, the perennially drought-stricken state of Rajasthan stands to potentially gain the irrigation of over 75,000 hectares of desert land.

Critics of the project point on the other hand, to massive social and ecological (as well as financial) costs. ${ }^{4}$ These include the flooding of 245 villages in order to create the dam's reservoir, as well as the lands of another I40,000 farmers to make way for irrigation canals. Thousands more may be affected by the project, including farmers and fisher-folk downstream from the dam, whose livelihoods will be disrupted. It is also worth noting that a majority of those destined to be affected by the NVDP are from indigenous or "tribal" groups (known in India as adivasis - a term that has been both a political rallying point and a point of contention for such groups). Such groups are often displaced by large-scale development projects because their traditional homes and livelihoods are situated within resource-rich or previously under-developed areas.

In addition to these serious social costs, critics of the NVDP point to the heavy ecological and financial burdens that the planned projects will place on the region. The environmental impacts of the planned dams include the loss of dense forests, the extinction of rare and endangered wildlife, possible risk of tectonic instability and resulting earthquake activity, an increased danger of siltation and salinity, the loss of topsoil, and an increase in health risks from waterborne diseases such as malaria. ${ }^{5}$ The full cost of the terminal dam alone is estimated to reach 200 billion rupees (roughly $\$ 4.6$ billion), and its completion date is anticipated as some time in 2040.6 This dam project currently consumes 80 per cent of the irrigation and water budget of Gujarat (which, as primary beneficiary also bears the brunt of the financial costs) and draws much needed resources away from other water conservation efforts.

Given these considerable social, financial and environmental costs, it is unsurprising that there has been a long and sustained opposition to the dam projects within the Narmada Valley. Protests accompanied the very onset of the project in $\mathrm{I} 960$, as the inhabitants of six villages were displaced

4. Mridula Singh, Displacement by Sardar Sarovar and Tebri: A Comparative Study of Two Dams (New Delhi, 1992); Uday Turaga, "Damming Waters and Wisdom: Protest in the Narmada River Valley”, Technology in Society, 22 (2000), pp. 237-253.

5. Claude Alvares and Ramesh Billorey, Damming the Narmada (Penang, I988); K. Sankaran Unni, The Ecology of River Narmada (New Delhi, I996).

6. Y.K. Alagh, Mahesh Pathak, and D.T. Buch, Narmada and Environment: An Assessment (New Delhi, 1995), p. 35 . 
in order to house dam builders and officials in a new "construction colony" named Kevadia. These villagers have yet to be adequately compensated.7 Since those early days, many different groups have rallied against the project. Farmers and merchants, labour organizations, social workers, and even the occasional mainstream politician have all at various times joined the protests. ${ }^{8}$ However, perhaps the most vigorous and effective opposition has been mounted over the past two decades.

Opponents of the NVDP have criticized the plans on multiple grounds. They have decried the lack of transparency in all stages of the project design, from planning to implementation to mitigation. They have critiqued in particular the lack of public participation in all of these processes. While state governments, engineers, and technical experts quarrelled among themselves during the I960s and I970s, the villagers and farmers whose lands were to be submerged were kept mainly in the dark. By 1985 , as rumours ran rampant about their fate, inhabitants of the valley began to organize in order to demand greater access to information, and as a way of negotiating more equitable compensation packages with the various state governments. ${ }^{9}$ Several of these groups coalesced in 1987 into the NBA, an umbrella organization that brought together villagers, labourers, farmers, social and environmental activists, writers, scientists, academics, and a host of others to protest the project.

The NBA helped to raise other questions and concerns regarding the NVDP. They highlighted the fact that many of the anticipated gains from the dams are based upon inaccurate or exaggerated data, pointing out that technical flaws render the existing estimates of power generation, drinking water availability, and irrigation efficiency grossly exaggerated. ${ }^{\circ}$ The effect of this opposition has been to move the issue beyond the local context and to challenge the project at national and even international levels. The NBA, through mass public protests and a series of strategic alliances with international NGOs, convinced the World Bank (one of the major financial backers of the project as of 1985 ) to launch an independent review of the dams, which, after a thorough re-evaluation, denounced the plans and recommended that the World Bank withdraw from the project (which it did in 1994). ${ }^{\text {II }}$

7. Singh, Displacement by Sardar Sarovar and Tehri, p. 3i.

8. Amita Baviskar, In the Belly of the River: Tribal Conflicts over Development in the Narmada Valley (Delhi, 1995), pp. I96-239.

9. Rahmahtullah Khan, "Sustainable Development, Human Rights and Good Governance - A Case Study of India's Narmada Dam", in Konrad Ginther, Erik Denters, and Paul J.I.M. de Waart (eds), Sustainable Development and Good Governance (Dordrecht, I995), pp. 420-428. I0. "Rehabilitation Status of Sardar Sarovar Project as of February 2002", briefing notes prepared by Narmada Bachao Andolan; "Who Pays? Who Profits? A Short Guide to the Sardar Sarovar Project", flyer prepared by Narmada Bachao Andolan.

I I. For an overview of the work and findings of the independent review, see Bradford Morse and Thomas Berger, Sardar Sarovar: Report of the Independent Review (Ottawa, 1992). 
Nevertheless, despite the World Bank's departure, as well as that of other former financiers such as the Overseas Economic Cooperation Fund of Japan, plans for the project proceeded unabated, with the government of Gujarat taking the lead as chief proponent. Unable to draw on funds from the international development-financing community, Gujarat turned instead to investors and proceeded to finance the project through a series of bond issues, spending close to roo billion rupees by 2000 . The costs of building the dam mounted steadily as construction ground to a halt with a federally-mandated moratorium imposed in 1994 .

The following six years saw court battles fought between the NBA, the riparian states, and the central Indian government - legal arguments that focused primarily on issues of resettlement and environmental impacts. While these cases wound their way through the Indian legal system, the NBA at the same time continued its strategy of media and protest campaigns against various elements of the NVDP (such as the building of the Maheshwar Hydroelectric Project, a subsidiary dam in the scheme). On I 8 October 2000, in a controversial split decision, the Supreme Court of India ruled in favour of the states and central government and allowed construction of the dams to resume. ${ }^{12}$ By mid-200 I the height of the Sardar Sarovar Project (also known as the SSP, this is the terminal dam in the entire scheme) had been raised by several metres, despite the fact that several thousand families were yet to be rehabilitated. Even faced with such concerns, a year later the central government of India reaffirmed its commitment to the NVDP and the designs of Gujarat and the other partner states. In November 2002, the then Indian Water Resources Minister, Arjun Charan Sethi, proclaimed the SSP to be a "national project", one that the National Democratic Alliance government would support fully. ${ }^{\mathrm{I}}$ At the point of writing this article, the Indian Supreme Court has authorized the increase of the dam height by a further ten metres, considered to be a considerable victory for the dam proponents. Despite such proclamations, the NBA and its supporters continue their struggle against the building of the dams.

In the following section, I will look more closely at two of the leading voices on the NBA side of this struggle: Medha Patkar and Arundhati Roy. I will focus on their roles as popular intellectuals and framing specialists as writers and orators, political strategists and legal petitioners, as commentators and critics - exploring how they conceive of themselves and their relationship to the anti-dam campaign, and in particular, how they attempt to frame the Narmada struggle within the context of broader social justice struggles both nationally and internationally. Beyond the two

I2. Pablo Bose, "Judgement not Justice: The Supreme Court of India's Decision on Narmada and the Sardar Sarovar Projects", Harvard Asia Quarterly, 5 (200I), pp. I2-23.

I3. "Sardar Sarovar Being Treated As National Project, Says Govt", Outlook India, I8 November 2002. 
individuals I have chosen to profile, there are many others who are important to the struggle in the Narmada Valley, from both within and outside the region, who have lent their voices to the anti-dam campaign and who might be construed as popular intellectuals. They include academics, scientists, writers, civil servants - people like the activist and scholar, Vandana Shiva, or the Gandhian social activist, Baba Amte - as well as large numbers of village and community leaders who have helped to organize and mobilize the population in the Valley throughout the years. Such people act as interpreters and mediators, communicators and translators; they enable dialogue between disparate groups, across communities and across differences. But my focus remains on Patkar and Roy because they are seen by many to be leaders and eloquent spokespersons for the struggle.

\section{FACES OF THE ANTI-DAM MOVEMENT - PATKAR}

AND ROY

\section{Medha Patkar}

Medha Patkar has been the guiding force throughout the history of the NBA. Even before the Narmada issue came to dominate her life, Patkar had a strong background in social activism. Born and raised in a middleclass family in Bombay (Mumbai), her father a noted trade-unionist, her mother a social worker, Patkar's own schooling included an MA in Social Work from the Tata Institute of Social Sciences. Patkar originally went to the Valley in 1984 to pursue research on social inequality amongst tribal groups in northeastern Gujarat for a Ph.D. (also at the Tata Institute of Social Sciences). Soon she was to abandon her formal studies, settle in the Valley, and work with local community groups to help articulate their concerns and questions regarding the dam projects. Her work has gained her both praise and notoriety both within and outside India. In 1992 she was awarded the Right Livelihood Award (also known as the "alternative Nobel Prize") for her efforts; in 1993 the Goldman Environmental Prize, an annual award of $\$ 125,000$ presented by a US-based charitable foundation. ${ }^{I 4}$ Later, she participated as one of the twelve official commissioners of the World Commission on Dams, specifically on behalf of the NBA and the National Alliance of People's Movements, but more broadly as a representative of grass-roots campaigns for human and political rights. ${ }^{\text {IS }}$ In 2002 she acted as a "debt prosecutor" at the 2002 World Social Forum in Porto Alegre, Brazil, and she has also been a

I4. The Richard and Rhoda Goldman Foundation has presented, since 1990, six annual awards of \$125,000 each to "environmental heroes" as recognition for "their efforts in sustained and important environmental achievements"; http://www.goldmanprize.org.

I s. The WCD Commissioners; http://www.dams.org/commission/commissioners.htm. 
speaker at academic conferences and activist demonstrations across the globe. ${ }^{16}$

There are three main ways in which Patkar has worked to frame and articulate issues in the Narmada Valley. Firstly, she has helped to raise questions regarding the costs and benefits of the proposed projects in the NVDP such as the Sardar Sarovar Project (SSP). Secondly, she has worked not only to challenge the specifics of dam construction in the Narmada Valley and the shortcomings of particular projects, but indeed to critique the prevalent model of industrial development as a whole. Thirdly, she has attempted to link the struggles in Narmada with emerging global social justice movements against neoliberalism and globalization.

Patkar's work to evaluate critically and challenge the claims of project planners stems from her original studies in the Valley on the potential impact of the large dams on local communities. Very soon she began to realize that measures designed to mitigate such impacts were, at best, inadequate or lacked enforcement; at worst they simply did not exist. Widespread confusion and a serious absence of information characterized the situation in the Narmada Valley in the early I980s, following the announcement of the Narmada Water Dispute Tribunal's decision. In these early years, Patkar worked with the residents of thirty-three villages in the state of Maharashtra in an organization called the Narmada Dharangrast Samiti (Narmada Displaced People's Organization). ${ }^{17}$ The goal of this organization was mainly to work with state governments to provide better rehabilitation and resettlement packages. Such efforts were not uncommon in the Valley; indeed, numerous NGOs and social justice organizations worked steadily to improve compensation programmes for the displaced.

But over the course of her work on improving rehabilitation and resettlement packages, Patkar began to question the long-term sustainability of such an approach. As new studies called into question the true nature of the costs and benefits of the NVDP, and the displacement experiences of other dam "oustees" in India made compensation promises by governments appear suspect, Patkar and like-minded others in the Valley made a crucial break with their erstwhile NGO allies. Gujaratbased groups such as ARCH-Vahini had taken (in their view) the pragmatic or realist view that since the dams were going to be built anyway, their responsibility as social activists was to secure the best compensation for the displaced possible. Accordingly, such NGOs - often exerting political pressure by using nonviolent methods such as demonstrations and fasts (similar to tactics that the NBA also employed) - helped 
to create some of the most comprehensive rehabilitation and resettlement packages in India. ${ }^{18}$

Indeed, the work of ARCH-Vahini and other NGOs like it was hailed as "crucial", "immensely important", and "vital" by the World Bank's independent review. ${ }^{19}$ But the same report pointed out the limits to what such an approach might achieve in the face of much larger, systemic flaws in the project plans. True, the pragmatist NGOs had achieved considerable gains in improving potential compensation for those to be displaced by the dams. But, as Patkar and others pointed out, these gains were relatively minor in the grand scheme of the NVDP; the best packages had been negotiated between Gujarat and oustees in that state - yet only a fraction of the villages to be submerged were located in that region and the other states had yet to offer similar compensation, and little or no mechanisms existed for implementing, monitoring, or enforcing proposed regulations to safeguard the displaced.

Patkar and her allies, therefore, joined together in the coalition that was to become the NBA, and declared their outright opposition to the projects. It is here that Patkar began to articulate the second element with which she framed the Narmada issue: questioning the very model of development that demanded the construction of the NVDP. No longer did she simply call into question the viability and desirability of a particular dam or series of hydroelectric projects, but indeed of an entire vision of development. In an open letter to the Indian Prime Minister, Patkar argued that:

The assessment of large dams like the Sardar Sarovar cannot be made on the basis of the displacement-rehabilitation issue alone; other equally important aspects like the displacement and destruction, cost-benefit analysis and a realistic analysis of benefits are some of the necessary parameters. It would be irrelevant to discuss merely the rehabilitation aspect while disregarding the strong challenge from our organisation to the claims regarding the benefits from the dam. The dam will not solve the serious problem of water and drought of KutchSaurashtra regions while the distribution of the benefits too is not equitable and just. Knowing this, it becomes important to ask as to why the adivasis, peasants, and labourers should sacrifice their life and resources. Instead of spending most of the irrigation allocations of Gujarat on this single project, we appeal to concentrate all the attention, resources and power for true, sustainable, decentralised alternatives without the problem of displacement. ${ }^{20}$

In Patkar's view, what the NBA was questioning was the very "process of

I 8. John R. Wood, "Changing Institutions and Changing Politics in Rural Water Management: An Overview of Three Zones in Gujarat", in Tony Beck, Pablo Bose, and Barrie Morrison (eds), The Cooperative Management of Water Resources in South Asia (Vancouver, 1999), p. 203.

19. Morse and Berger, Sardar Sarovar, pp. I29-13I.

20. Letter from Medha Patkar to the Prime Minister of India, A.B. Vajpayee, 28 September 1999, NBA Press Release, io October 1999. 
development planning, right from deciding the development goals as well as managing the natural resources". ${ }^{21}$

She argued that those most affected by the NVDP had been ignored by previous planning processes, including the Water Disputes Tribunal as well as the official political and bureaucratic apparatus. Their participation had been neither sought nor welcomed. She complained that local people lacked access to information regarding the very plans that would impact their lives, and that what was publicized generally consisted of highly exaggerated benefits and promises. Patkar argued that this was part of a systematic process of deceit and domination that kept people ignorant, and by which elite sections of society were able to exploit others, particularly the rural poor:

The point is that the communities which are based on the natural resources are compelled to sacrifice those resources in the name of development, with the principle of eminent domain that the state resorts to. The state takes away these natural resources from the communities, the fish workers, the farmers, or manual labourers. It certainly stands by the marketized, industrialized, urbanized communities, and that small section of the society then uses these resources or the benefits drawn out of these resources at the cost of all those who loose theirs. This society certainly doesn't give a real share in the benefits to those who sacrifice their land, water, forests. This is considered as a part and parcel of development and the tradeoff that is necessary. ${ }^{22}$

Patkar also criticized the role that the state - and in particular in India, the developmental state - had played in not safeguarding the rights and lives of the very people in whose name it was carrying out massive development projects. She argued that the state did not act as a neutral arbiter between competing interests, nor did it protect oppressed minorities from manipulation and exploitation. In somewhat Gandhian terms, Patkar characterized the state, instead, as concretized violence, as an institution that employs its security apparatus to intensify accumulation by elites. ${ }^{23}$

Her critiques of the Indian state did not lead Patkar to abandon the national political sphere as an arena of struggle. Nor did the reframing of the Narmada debate as one on development rather than on the shortcomings of one dam, lead her to abandon her specific criticisms of the Sardar Sarovar Project. Instead, what Patkar and the NBA did was to pursue a multi-faceted approach to their campaigns, adopting a "comprehensive, polito-economic, social ideology, which may not come merely from Gandhi or Marx, but a combination of various [analyses], tools that

21. Medha Patkar, interviewed by Venu Govindu, Friends of River Narmada, 9 August 1999.

22. Ibid.

23. Medha Patkar, interviewed by Sonya Thimmaiah, Friends of River Narmada, 6 May 200 I.

24. Medha Patkar, interviewed by Venu Govindu, Friends of River Narmada, August 1999. 
all of them have offered to us". ${ }^{24}$ At the local level, the anti-dam campaign continued to study the project planners' designs and their possible impacts, intervening with direct action and media campaigns when required. Nationally, Patkar in particular focused the attention of India's urban middle class on Narmada as a crucible for the nation's postcolonial development strategy by repeatedly asking why certain sacrifices were being sought and for whom. The NBA worked within the structures of the state - launching court petitions, negotiating at times with local politicians, participating fully in debates within the public sphere - as well as pursuing their direct-action strategies of political protest (including fasts, marches, rallies, sit-ins) in ways deemed sometimes illegitimate by the state.

But perhaps Patkar's most important move - both tactically and theoretically - in framing the issues of the Narmada Valley was to link them more explicitly with similar struggles elsewhere in the country and around the world. The campaign that the NBA launched against the World Bank, for instance, was successful in part because of the direct challenge that the protests by the displaced made against the Bank's President and officers in New Delhi, but also because of alliances that the NBA was able to form with international NGOs. Patkar in particular worked with the Environmental Defence Fund (Washington DC), International Rivers Network (Berkeley, California), and Friends of the Earth (Japan) during this period, and personally made appeals to various political bodies (including the Japanese Diet and the United States Congress). ${ }^{25}$ The antidam movement also received considerable support from a NorthAmerican based support network comprised of diasporic South Asian students and young professionals that calls itself "Friends of River Narmada", hosts a website, and conducts media campaigns in the United States and Canada. ${ }^{26}$

Such alliances have been crucial to the success of the NBA, argues Amita Baviskar. ${ }^{27}$ She suggests that the NBA has protected itself by tapping into a worldwide discourse of relatively affluent middle-class environmentalism, whereas other movements in the same region that have explicitly organized on behalf of indigenous or workers' rights have been much more brutally repressed by the state. It is noteworthy that the NBA has made its strongest international alliances with NGOs such as the International Rivers Network, Friends of the Earth, and Environmental Defense Fund, rather than Amnesty International, or Human Rights

25. Lori Udall, "The International Narmada Campaign: A Case of Sustained Advocacy", in Fisher, Toward Sustainable Development, pp. 20I-227.

26. Friends of River Narmada's website can be viewed at http://www.narmada.org.

27. Amita Baviskar, "Environmental Identities: The Politics of Nature and Place in India", Asian Environments Series, York Centre for Asian Research, York University, Toronto, Canada, 24 November 2003. 
Watch. Such connections, though they have proved fruitful, have also helped to buttress criticisms that the NBA works on behalf of external, middle-class interests, rather than those of local people, an issue that will be addressed further below.

One of Patkar's greatest assets has been an ability to speak with equal facility to a range of audiences - local communities, grass-roots activists, international NGOs, national and international politicians, academics and scientists, and a host of others. Patkar's skills with translation across experiences and idioms has thus greatly enhanced the NBA's strategy of building networks and coalitions of support. Within India, for example, the NBA has helped to found the National Alliance of People's Movements (NAPM), a group that brings together diverse local struggles such as hawkers in Bengal, mining communities in Orissa, fisherfolk from the coasts of India's south, and people affected by displacement-inducing development schemes all across the subcontinent. ${ }^{28}$ Patkar sees such linkages as crucial to the success of the movement in the Narmada Valley:

At another level, the NBA has always been relating to the wider struggle. NBA to NAPM, that process does not merely [mean] going to different struggles and then saying, "We support you, and you support us." It means building a comprehensive ideological position and taking local to national action. Now with globalization and liberalization, which we are opposed to completely, we need to link up struggles like Narmada with other struggles. All these years we have been fighting a centralization that is undemocratic, unsustainable and unjust. And now it is the same centralized power and structure that has been hijacked to a global level. We have to fight that also.. ${ }^{29}$

The connections that Patkar has attempted to draw between the struggles in the Narmada Valley and those elsewhere within India and the rest of the world has had several effects. From a tactical perspective, such connections have helped the anti-dam movement to mobilize effective support networks, when needed, to confront specific threats to its cause. For example, during the campaign carried out between I9992002 against the building of the first privately-constructed and operated dam in the NVDP, the Maheshwar Hydroelectric Project, the NBA was able to draw on allies such as the German NGO, Urgewald and the North American-based Friends of River Narmada to bring pressure to bear upon German and US partners in the project. ${ }^{30}$ These NGOs confronted financiers, utility corporations, and engineering firms on their involvement in the project, highlighting the social and environmental costs of this project in particular. Simultaneously, the NBA carried out protests, rallies, and other direct action to pressure the Indian partners and local develop-

28. Medha Patkar, interviewed by Venu Govindu, Friends of River Narmada, August 1999.

29. Ibid.

30. Heffa Schücking, "The Maheshwar Dam in India”, Urgewald briefing report, March 1999. 
ment authorities to rethink their plans. This two-pronged approach resulted in the eventual withdrawal of foreign partners from the project and an eventual suspension of construction activities.

In a strategic sense, however, Patkar's framing of Narmada as a global issue has been perhaps even more important. As mentioned at the outset, the Narmada case is well-known within international development circles. But it has equally become a test not only of development within India, but of development globally. By participating in processes such as the World Social Forum and the World Commission on Dams, and by explicitly declaring that the struggle in Narmada is part of a global struggle, Patkar has helped to redefine a locally oriented, place-based social movement in ways that might potentially move it away from a framework of local interest and towards one of international solidarity and support. Such a framing approach has been similarly undertaken, perhaps even more overtly, by the second popular intellectual in the Narmada case on whom I would like to focus, the novelist Arundhati Roy.

\section{Arundhati Roy}

Originally trained as an architect, Arundhati Roy was born in Bengal, raised in a small village in coastal Kerala, and is currently a novelist living in Delhi. ${ }^{3 \mathrm{I}}$ Her parents - a Bengali Hindu father and a Syrian Christian mother - divorced during her childhood, and Roy's mother became wellknown for winning a public-interest litigation case challenging Kerala's Syrian Christian inheritance laws in 1986. Roy came to the Narmada Valley as an already established celebrity, a writer who won the Booker Prize in 1997 for her novel, The God of Small Things, a book that has sold six million copies and has been translated into forty languages. She donated the prize monies she received for this critically and commercially successful work to the NBA and has since been a passionate advocate for the struggle in Narmada, writing polemical essays, articles, letters, and books on the subject, and participating in marches, rallies, and other forms of protest. ${ }^{32}$ While Roy's involvement with the Narmada issue has begun much more recently than Patkar's, her impact and notoriety has been considerable. Like Patkar before her, Roy has critiqued the NVDP on multiple levels - from problems regarding specific project plans, through broader issues regarding regional and national development policy, to global political and socio-economic struggles.

31. Arundhati Roy, interview by David Barsamian, The Progressive, 65 (2001), pp. 33-39.

32. Arundhati Roy's writings include Narmada-related publications such as: The Cost of Living:

The Greater Common Good and the End of Imagination (New York, I999); Power Politics (Cambridge, MA, 200I); and newspaper editorials such as "Lies, Dam Lies and Statistics", The Guardian, 5 June 1999; "The Greater Common Good I", Outlook India, 24 May I999; and "The Greater Common Good II", Outlook India, I 2 July 1999. 
In The Cost of Living (1999), a book comprised of the essays "The Greater Common Good", and "The End of Imagination", which provide in tandem a critical examination of India's developmental and nuclear policies, Roy focuses specifically on Narmada and writes:

In India over the last ten years the fight against the Sardar Sarovar Dam has come to represent far more than the fight for one river. This has been its strength as well as its weakness. Some years ago, it became a debate that captured the popular imagination. That's what raised the stakes and changed the complexion of the battle. From being a fight over the fate of a river valley it began to raise doubts about an entire political system. What is at issue now is the very nature of our democracy. Who owns this land? Who owns its rivers? Its forests? Its fish? These are huge questions. 33

In her later book, Power Politics (200I), Roy sustains her critique, drawing a portrait of a clash between developmental visions by using a metaphor of two different vehicles on separate trajectories. One occupied by a small minority - is on a road towards increasing opulence and privilege, while the other - by far the more crowded, and becoming increasingly so - is headed towards marginalization and oppression. She argues that "India lives in several centuries at the same time", and that the contradictions can be seen in the "road gangs of emaciated labourers digging a trench to lay fibre optic cables to speed up our digital revolution". ${ }^{34}$ It is these sometimes grotesque contradictions that, Roy argues, need to be acknowledged in modern India (and indeed elsewhere around the globe) as it struggles on the edge of the social and ecological crises that mark the new millennium. These should not simply be swept away in the glare of a burnished modernity, or accepted as a cost of doing business. Cases such as the struggle in the Narmada Valley can teach important lessons about the real costs of modernist fantasies, Roy argues:

Curiosity took me to the Narmada Valley. Instinct told me that this was the big one. The one in which the battle-lines were clearly drawn, the warring armies massed along them. The one in which it would be possible to wade through the congealed morass of hope, anger, information, disinformation, political artifice, engineering ambition, disingenuous socialism, radical activism, bureaucratic subterfuge, misinformed emotionalism and, of course, the pervasive, invariably dubious, politics of International Aid.35

Like Patkar, Roy has depicted the Narmada struggle as more than a sitespecific or contained incident. The issues that Roy and Patkar speak about are similar ones, and if Roy does not have the long history of involvement with the Narmada issue that Patkar does, the extensive research she has 
done on the facts of the case to buttress her arguments makes it clear that Roy has taken the time to look very carefully at the ways in which life in the Valley may be irrevocably altered by big dams. Both Patkar and Roy would argue that the NVDP is not an aberrant situation, in which poor design, implementation, corruption, or enforcement has undermined an otherwise reasonable system. It is the very theoretical underpinnings and normative frameworks of that system that need to be critically interrogated and overhauled.

But while Patkar and Roy's framing of the issues are often quite similar, their presentation of their arguments can be somewhat different. Patkar, as noted earlier, speaks to a range of audiences and in a range of voices, from impassioned political speeches to reasoned scientific and academic debates. Roy has written and spoken mainly to a middle-class audience, both within India and internationally, and her work has been perhaps more pointedly acerbic and political (so much so that she was slapped with a Supreme Court of India contempt charge, for which she served a token day in jail). ${ }^{36}$ She has been criticized for her style of argumentation, as will be examined more closely in the next section. But Roy argues that there is little distinction between her work as a novelist and as an essayist and activist:

I don't see a great difference between The God of Small Things and my works of nonfiction. As I keep saying, fiction is truth. I think fiction is the truest thing there ever was. My whole effort now is to remove that distinction. The writer is the midwife of understanding. It's very important for me to tell politics like a story, to make it real, to draw a link between a man with his child and what fruit he had in the village he lived in before he was kicked out, and how that relates to Mr Wolfensohn at the World Bank. That's what I want to do. The God of Small Things is a book where you connect the very smallest things to the very biggest: whether it's the dent that a baby spider makes on the surface of water or the quality of the moonlight on a river or how history and politics intrude into your life, your house, your bedroom. 37

What Roy has done through her essays and her other writing has been to sustain, and perhaps even enlarge, the arguments that Patkar and the NBA have been making for over two decades: that the struggle in the Narmada Valley is part of a much greater fight for social and ecological justice that is going on across the world. By telling the story as she sees it to an audience that she is familiar with, Roy is trying to make visible a reality that has been all too often ignored. For example, while the violence, suffering, and displacement of over five million people that accompanied the British

36. For more on the contempt of court case, see Supreme Court of India Original Jurisdiction I.A. No. I 4 of 199 Writ Petition (Civil) No. 319 of 1994, NBA (petitioner) vs. Union of India and Respondents.

37. Arundhati Roy, interview by David Barsamian. 
Partition of the Indian subcontinent during Independence remains seared on the nation's soul, the fact that as many as fifty million people have since been uprooted and impoverished in the name of dam-building and other development projects is much less widely acknowledged. ${ }^{38}$ Roy's writing seeks to reach those on whose behalf development and the project of modernity proceeds - the wealthy, the middle-class, and the urban privileged, in India as much as in the rest of the world.

The work that Patkar and Roy have undertaken, the context and connections that they constructed in publicizing the struggles in the Narmada Valley, have been largely successful in ways indicated above. But these efforts have not gone without challenge. In the following section, I will explore some of the criticisms that have been levelled in recent years at the NBA, and at Roy and Patkar in particular.

\section{CRITICISM OF THE NBA, PATKAR, AND ROY - THE OMVEDT DEBATE}

The work of the NBA and of Patkar and Roy has had its share of criticism over the years. Proponents of the projects have reviled the leaders of the NBA as glory-seekers, and militant martyrs, leading a manipulated flock down a destructive path. They have been called uninformed "ecoromantics", "backward radicals", and "alternative society counter-culture ideologues", adamantly and irrationally opposed to any development in the Valley.39 They have been charged (and as noted in the case of Roy, convicted) with contempt by the Supreme Court of India for their criticism of its decisions. Some argue further that Patkar and Roy's position ultimately dooms the inhabitants of the Valley and robs them of the opportunity to better their lives, substituting a grand vision of revolution for small, practical, and achievable change in their daily existence $4^{\circ}$ Others critique Patkar and Roy for their supposed lack of insider legitimacy - they are not "from" or "of" the Valley in such a reckoning, and thereby ostensibly unqualified to express an opinion on its fate.

Some of these critiques can be dismissed as spurious or ill-conceived, others are simply false or the rhetorical flourishes of those who have a vested interest in the continuation of the NVDP. But in 1999, a more serious challenge to the work of the NBA and its leaders and supporters

38. Ashish Kothari, “The Development Debate”, Humanscape, 6:1 I (November 1999).

39. B.G. Verghese, Winning the Future: Bhakra to Narmada, Tehri, Rajasthan Canal (Delhi, I994), p. I.

40. John R. Wood, "Struggles within Struggles: Indian NGO Politics and the Narmada Dams Controversy", in Hugh Johnston, Reeta C. Tremblay, and John R. Wood (eds), South Asia Between Turmoil and Hope (Montreal, 1999), pp. 235-260. 
was raised by Gail Omvedt, an American-born anthropologist who, along with her husband, has been actively involved in women's and farmers' organizations in the state of Maharashtra. Omvedt's scholarly and activist work has centred on new social movements, campaigns for women's empowerment, property rights, political representation, involvement in sustainable agriculture, anticaste, and environmental struggles. ${ }^{4 \mathrm{I}}$ In recent years she has been involved in a series of debates with self-identified leftist voices within Indian academia and polity regarding the purpose, nature, and implementation of liberalization and globalization, which she has argued in favour of as a qualified necessity. Omvedt's debates on these subjects have included strong criticisms of certain social movements and organizations, especially "radical” environmental movements and Roy and Patkar in particular.

The criticisms that Omvedt raised were certainly not new ones, and concern familiar debates regarding social movement strategy that often take place in activist and academic circles within India and elsewhere. However, Omvedt brought her questions up in a very public forum, with a series of open letters and articles published in the Indian English-language press. Omvedt's arguments were aimed primarily at Roy, with Patkar and the NBA as subsidiary (though significant) targets.

Omvedt raised several concerns. She criticized Roy's conflation of the nuclear issue with the developmental agenda of big dam building. In Omvedt's view, dams were not an unalloyed evil, and for the NBA and its supporters to oppose them on principle was both irresponsible and a betrayal of the ultimate need for sustainable development by villagers in the Narmada Valley. Omvedt argued that, in building the international alliances that the NBA felt were necessary for its survival and success, the anti-dam movement's "small local base" of landless labourers and small farmers and their concerns were being subsumed to the interests of a global, affluent upper-middle class of environmentalists. Omvedt went so far as to suggest that "the NBA has become the voice of the ecoromanticists of the world", of an environmental movement "caught in an extremist trap"..$^{2}$ She argued that their haste to appease these middle-class interests had led the NBA to ignore the real needs of the marginalized in the Valley and elsewhere, and even to ignore smaller-scale alternatives to the big dams.

Omvedt strongly opposes Roy and Patkar's assertion that big dams are

4I. Gail Omvedt's recent publications include Reinventing Revolution: New Social Movements and the Socialist Tradition in India (Armonk, NY, 1993); Dalits and the Democratic Revolution: Dr Ambedkar and the Dalit Movement in Colonial India (New Delhi [etc.], 1994); Dalit Visions: The Anti-Caste Movement and the Construction of an Indian Identity (New Delhi, 1995); "Reflections on the World Bank and Liberalization", Bulletin of Concerned Asian Scholars, 27 (1995) pp. 4I-43; and "Caste and Hinduism”, Economic and Political Weekly, 29 November 2003. 42. Idem, "Dams and Bombs - II", editorial, The Hindu, 5 August 1999. 
evil; instead, she makes the argument that it is only poorly planned ones that have disastrous outcomes. Omvedt suggests that, for the NBA, "their main concern is to question the entire goal of development itself" 43 - a statement that Patkar and Roy would no doubt agree with wholeheartedly (though obviously not in the negative light in which Omvedt casts their views). Omvedt argues that their opposition to industrial development as a matter of principle has trapped Roy and Patkar into a static and unrealistic view of the past, fighting to preserve the "village life" of the Narmada Valley without acknowledging the multiple hierarchies, oppressions, and structural constraints which frame those living within. How can social change occur, Omvedt asks, with only backward-looking models?

But perhaps the most difficult questions that Omvedt raises have to do with the nature of the NBA and the anti-dam movement itself. She criticizes Patkar for failing adequately to acknowledge the organizing that had been done prior to her arrival in the Valley, and for insufficiently answering the questions of legitimacy and representation. Omvedt quotes an adivasi activist who had asked of the NBA, "Why is it that there is no top ranking adivasi leadership in the NBA?" 44 Omvedt complains that there has been no real answer given to this query, or her related question, "Why are all the leaders from the urban elite, and how democratic exactly is their relationship to the rural poor they are organizing?" 45 She points to the NBA's use of the term "tribal" as further evidence that the NBA leadership is out of touch with its grass-roots base - she mentions the negative connotations of the word and its disavowal by many who have been identified (and marginalized) by it.

Underlying all of Omvedt's attacks on Patkar and Roy, there is a sense that she is questioning the legitimacy of their leadership because they are outsiders to the Valley, urban interlopers in a rural dispute. In her eyes, there is a crisis of representation between the NBA and the farmers, labourers, merchants, and villagers. She suggests to Roy that:

There is nothing wrong with going out to organize people, with throwing oneself into a cause or supporting a cause, with rallying world opinion. NBA has succeeded in giving great power to a "no-big-dam" position and in putting a big question mark before the whole issue of "development". You have every right to support them. But in doing so, please think about one thing: when you go as leaders to people in the valley, or when you represent people in the valley to the world outside, what are the consequences for them of the arguments you make? What does it mean when you put your own arguments, either explicitly or implicitly, in their mouths? Are you so sure your sweeping opposition to big

43. Idem, "The Trouble with Eco-Romanticism and the NBA", Humanscape, 6:I I (November I999).

44. Waharu Sonavane, quoted in ibid.

45. Omvedt, "The trouble with Eco-Romanticism and the NBA". 
dams is in their best interest, or that you are democratically representing their real feelings on the matter? ${ }^{4} 6$

The point Omvedt is making is crucial and one that is difficult for Roy, Patkar, or the NBA to answer: how does this movement address the issue of representation? In what ways does the leadership survey the desires and sentiments of its constituency? How does the NBA even know what their constituency is, given its fluid and amorphous nature? There are, after all, no party memberships in a people's movement, no annual dues paid by the rank-and-file, no real way of keeping track of support. The NBA must rely instead upon the support for their actions shown by local inhabitants of the Valley as well as outsiders, as evidenced by their participation in various rallies, marches, protests, and village and town-level public meetings. Such participation has been consistently shown throughout the history of the NBA. Still, Omvedt's caution is an important one.

As a respected scholar of social movements and someone with no vested interest in the continuation of the NVDP, Omvedt's observations were taken seriously and answered in a series of open letters and editorials by other activists and scholars. ${ }^{47}$ Though they understood and sympathized with certain aspects of her critique, many were dismayed by the timing of her intervention, coming as it did when the battle over the Narmada Valley was reaching a crescendo in the court system. Others dismissed Omvedt's arguments as occasionally ill-informed and misleading, selectively choosing to highlight some facts and to minimize others. Some pointed out that, in her own polemic, Omvedt had conveniently ignored the NBA's study of positive alternatives to the big dams. They argued that, far from a "small local base", the NBA had a sizable grass-roots constituency, as evidenced by the tens of thousands who participated in rallies, marches, and protests organized by the NBA. Others took issue with Omvedt's defence of big dams, pointing to the extensive evidence indicating their deleterious effects. Some intimated that Omvedt's criticisms were driven by pique rather than reason, pique at the relative success enjoyed by the NBA over that of the anti-dam campaign that Omvedt had been involved with. $4^{8}$

With regard to the question of legitimacy and representation, Ashish Kothari of the environmental education and research NGO, Kalpavriksh - an intellectual and activist with his own long history of involvement with the Narmada issue - remarks:

46. Ibid.

47. For responses to Omvedt, see in particular, Kothari, "The Development Debate"; Nalini Nayak, "Response to Gail Omvedt's Open Letter to Arundhati Roy", National Fishworkers Forum Press Release, i I August 1999; Himanshu Thakkar, "Sardar Sarovar and the Bomb", South Asia Network on Rivers, Dams and People Press Release, November 1999.

48. Ashish Kothari, "Dams, Bombs and Development", Opinion, The Hindu, I7 August 1999. 
The question of why there is no "top-ranking adivasi leadership in the NBA", is important, and needs to be squarely addressed by NBA itself. But it is not a question restricted to the NBA, it can be asked of most recent movements in India. Perhaps it has to do with the history of displacement of adivasi identity, perhaps something else. Perhaps it has to do with the way in which the Indian and international media singles out "heroes" they are comfortable with, or who belong to their "class". What is absolutely clear, however, is that in the decisionmaking process in the valley itself, both adivasis and non-adivasis are highly involved, even though Medha and other "middle-class" activists do often have a stronger say. 49

Issues of insider legitimacy and of appropriation and agency are crucial for all progressive social movements to consider. What exactly is being advocated? On whose behalf? On whose authority? These are questions that need to be, as Kothari puts it, "squarely addressed". By portraying the NVDP in the manner that they do, are Patkar and Roy accurately representing the perspective of the people about to be displaced by the dams? Do the inhabitants of villages like Jalsindhi and Manibeli and Domkhedi see their struggles as intimately linked to those of roadside vendors in Kolkata or street sweepers in Mumbai - or indeed to the urban poor in Cochabamba and the homeless in Chicago?

These are tensions that are perhaps the most difficult to resolve within any social movement, and the NBA is no different. Patkar, Roy, and their supporters would argue that they are intimately close to the people on whose behalf they advocate - much closer in fact than the governments and development agencies who themselves undertake their projects in the interest of the "greater good". Patkar lives and works and is prepared to die in the Valley if it is to be submerged by the dam. Roy has always claimed to be a writer and a reporter of events and situations, rather than the demagogue others accuse her of being. She states flatly, "I don't ever want to portray myself as a representative of the voiceless". 50 While Patkar and Roy have been identified as leaders by the media, and on occasion by themselves, their more crucial role has been that of critics, reporters, and translators, reaching diverse audiences in a variety of ways. It is also true that the struggle in the Valley cannot be reduced to simple dichotomies between "insiders" and "outsiders" - or indeed, between industrial development on one side and local communities on the other, as it is sometimes cast. The constituency of the NBA reflects many disparate backgrounds and interests, including both rich farmers who use technology-intensive and industrial agriculture, and hill adivasis who were once displaced and continue to be exploited by them. ${ }^{\text {II }}$ The success and strength

49. Kothari, "The Development Debate".

50. Arundhati Roy, interview by David Barsamian, p. 39.

51. Baviskar, In the Belly of the River, pp. 219-222. 
of the NBA has been in welding together these historically antagonistic groups by focusing them on the common goal of halting construction on the dam. In the final section of this paper, I will look at some of the lessons that can be learnt from the Narmada experience regarding popular intellectuals and social movements.

\section{POPULAR INTELLECTUALS AND THE NARMADA VALLEY - PITFALLS AND POSSIBILITIES}

The case of the anti-dam movement in the Narmada Valley demonstrates the pivotal role that popular intellectuals can play in the organizing, sustaining, and widening of specific struggles. It also shows the contested and evolving nature of intellectual labour in the service of progressive social movements. How are relationships with those outside the movement negotiated? How are internal differences resolved and decisions arrived at? In the words that Patkar and Roy use to describe their own efforts, in the critique of Omvedt, and in Kothari's response, there is a definite prescriptive element. That is, there is a strong - if relatively undefined - set of assumptions regarding what the role of the popular intellectual should be. In such a reckoning, popular intellectuals should support a movement, not supplant its objectives with their own. They should avoid vanguardist tendencies or speaking for others without their consent. And, above all, such intellectuals should remain committed and connected to their base of support at all times. In their articulation of particular problems, they should remember on whose behalf they operate, and to what effect. Indeed, the idea that Roy, Patkar, and the NBA have not remained faithful to such a set of assumptions lies behind many of the charges levied at them by their critics.

But the question of the place and purpose of popular intellectuals - or of intellectuals at all - with regard to social movements is not confined to the Narmada case; indeed, the question has long been debated within activist and academic circles. Some argue for Antonio Gramsci's idea of the "organic intellectual", knowledge-workers firmly grounded in the everyday struggles of the communities from which they arose, situated in a

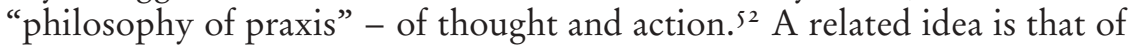
Foucault's "specific intellectual", which similarly insists on the intellectual situating his or her work "within specific sectors, at the precise points where their own conditions of life or work situate them".53 Issues of distance or disconnection between intellectuals and social movements may be overcome, then, when intellectuals are self-consciously embedded

52. Antonio Gramsci, Selections from the Prison Notebooks, Quentin Hoare and Geoffrey Nowell Smith (eds and tr.) (New York, I97I), p. 9.

53. Foucault, "Truth and Power", p. I 26. 
within particular contexts. Some have taken this to mean that popular intellectuals must therefore be representatives of a particular struggle on the basis of their identity rather than their function. In such a conception, indigenous movements would be led by indigenous intellectuals, workers' movements by workers, and so on.

The reality is of course that social movements across the globe are not, by and large, dominated by voices "from within"; that is, by intellectuals who have arisen from the social categories whose aspirations they claim to articulate. Instead, those who write about issues, give speeches to crowds, negotiate with governments, study the impacts of proposed plans, organize rallies and marches, and act as the face and voice of social movements are still overwhelmingly drawn from the upper and middle classes of educated elites. Does this "distance" or apparent lack of authenticity negate their contribution? Patkar strongly rejects such a position, pointing out the important role that the city-based intelligentsia has played in the anti-dam campaigns:

In the Narmada movement, we have found that while the struggle had its main base in the valley, these [urban] kinds of support groups played a very different role. Analysing designs and plans, finding roots and targets of development, defining our strategies - these are roles that urban intelligentsia can take. Others can disseminate information through the media and so forth. And if you have strategies which cannot be restricted to village level action - when you have to come out on the streets - you need urban supporters. You need lawyers. As long as you need support from within the system to fight the system - just like you need a thorn to remove a thorn - you need such support. That has to be one front of the movement. 54

Roy is equally vehement in her response, arguing that the charge of inauthenticity is misleading and misguided:

You can't expect the critique to be just adivasi. You isolate them like that, and it's so easy to crush them. In many ways, people try to delegitimize the involvement of the middle class, saying, how can you speak on behalf of these people? No one is speaking on behalf of anyone. The point is that the NBA is a fantastic example of people linking hands across caste and class. It is the biggest, finest, most magnificent resistance movement since the independence struggle. 55

One of the dangers of adhering too strongly to a set of prescriptive assumptions regarding the role of the popular intellectual is of focusing more on their background than on their function. Many have asked whether intellectuals from elite backgrounds can ever radically interrogate their own subjectivity, privilege, power, and authority enough to participate actively in movements for social transformation. This is a fair

54. "You Need a Thorn to Remove a Thorn", interview with Medha Patkar.

55. Arundhati Roy, interview by David Barsamian. 
question. As anticolonialist struggles have long asked, "can an oppressed [group] rely on knowledge produced by others, no matter how progressive, who are members of an oppressor [group]?" ${ }^{6}$ But to argue that only intellectuals who belong to underprivileged classes are able adequately to represent the latter's objectives is both misguided and short-sighted. Insisting on an authenticity of voice and representation suggests that a fixed, homogenous identity is possible. But identities are never so static, even if polarizing struggles such as that over Narmada might portray them as such. Kothari goes so far as to suggest that the category of middle-class urban activists is no longer "a valid real-life category" 57 for describing the leadership of the NBA, many of whom have dedicated their lives to the struggle and have settled in the region. Are the interventions of such activists deemed less valuable because of their lineage?

Part of the problem lies with the framing that popular intellectuals must utilize, whether out of necessity or as part of a longer-term strategy. Patkar, Roy, and the NBA have at times cast their struggle in terms of monolithic, reductionist, and stereotypical dichotomies - industrialization vs small-scale development, rich urban elites vs rural poor, modernity vs tradition. The use of such essentialist rhetoric has been strategic - both Patkar and Roy are well aware of the multiple oppressions within which the participants of the anti-dam movement operate, of gender, caste, class, religion, even language. They are equally aware that "locality" is not an inherently positive space, but may foster, instead, parochialism, inequality, and domination. When Patkar and Roy and the NBA rally their supporters around notions of the local, and against the "outside" influence of actors such as the World Bank and development planners, they run the risk that their rhetoric of "strategic essentialism" occasionally exceeds their reach..$^{8}$ Patkar and Roy do not claim to defend the status quo - as Roy says, "I've spent my whole life fighting tradition. There's no way that I want to be a traditional Indian housewife. So I'm not talking about being antidevelopment. I'm talking about the politics of development, of how do you break down this completely centralized, undemocratic process of decision-making." 59

How Patkar and Roy framed the core issues of the protest is, therefore, double-edged in its effect. Aimed at multiple audiences, their message has straddled diverse and sometimes contradictory discourses on develop-

56. Nkululeko, quoted in Deborah Kasente, "The Gap Between Gender Research and Activism in Uganda", in Obioma Nnaemeka (ed.), Sisterhood, Feminisms and Power: From Africa to the Diaspora (Asmara, 1998), p. 227.

57. Kothari, "Dams, Bombs and Development".

58. For the term "strategic essentialism", see Gayatri Chakravarty Spivak, "Subaltern Studies: Deconstructing Historiography”, in Donna Landry and Gerald MacLean (eds), The Spivak Reader: Selected Works of Gayatri Spivak (New York, 1995).

59. Arundhati Roy, interview by David Barsamian. 
ment, social justice, human rights, community-building, and nationhood. What has been their strength in one arena - their emphasis on the very real connection felt by local inhabitants to their lands and livelihoods - has been used by others in other contexts to critique them for their romanticism and nostalgia. The framing process is not entirely under the control of Patkar, Roy, and the NBA, however. The presentation of the social movement by and to others is mediated by other actors, not least of which is the commercial mass media. ${ }^{60}$ Within India, there is even a considerable difference in the reporting of the Narmada issue between the different regional and linguistic news media. Even beyond the press, narratives of struggles such as those in the Narmada Valley tend to be mediated by hegemonic discourses, ones that tend to privilege those who can speak in the dominant languages. This is part of the reason we hear so often from Patkar and Roy in their own words, articulate, passionate, and able to speak in a variety of languages and contexts. We catch only brief glimpses of the other people who live in the region, as the subjects of newspaper articles, academic studies and conferences, political rallies and films.

But despite these tensions and contradictions, Patkar, Roy and the NBA have been able to produce a considerable impact. Their ability to frame the struggle in the Narmada Valley over the building of dams at multiple levels simultaneously has enabled the movement to grow and survive. It has enabled them to challenge diverse and ever changing opponents, from local politicians to regional and national development authorities, from international financial institutions to multinational corporations. Their framing of the Narmada issue as both an ecological and a social justice issue has afforded the movement greater protection than others that have fought for human rights alone. Above all, the explicit linking of local, national, and international issues by Patkar and Roy has resulted in the type of multi-level "scalar politics" that is, according to Arturo Escobar, a necessary approach for contemporary social movements in the context of increasing globalization. ${ }^{61}$

60. Todd Gitlin, in his study of student antiwar activists during the I960s, argues that the mass media keys on readily identifiable and "marketable" leaders of such social movements and transforms them into celebrities for audience consumption. For more, see Todd Gitlin, The Whole World is Watching: Mass Media in the Making and Unmaking of the New Left, with a new preface (Berkeley, CA, 2003).

6r. Arturo Escobar, "Displacement, Development, and Modernity in the Colombian Pacific", International Social Science Journal, 55 (2003), p. 5 , and idem, "Culture Sits in Place: Reflections on Globalism and Subaltern Strategies of Globalization”, Political Geography, 20 (200I), pp. I $39-174$. 